\title{
Inventory Optimization with Stock-Level Dependent Demand, Shortages and Variable Holding Cost
}

\author{
Sandeep Kumar \\ Dewan V S Group of Institutions, Meerut, India \\ Available online at: www.isroset.org \\ Accepted 18/Aug/2018, Online 30/Aug/2018
}

\begin{abstract}
In the present study the optimal order quantity and the time of optimal cycle of an inventory model are determined. Here the rate of demand depends on the stock. The holding cost per unit of the item per unit time is taken to be linear function of the quantity in storage. Here, it also considered that the shortages in stock are allowed. In traditional inventory models, the rate of demand and holding cost are considered to be constant. There are so many inventory models, where the holding cost was taken to be constant for the whole inventory cycle without shortages. But here the holding cost is considered as a variable which is an increasing step function of the time due to storage. This study provides the basis for further extensions like the incorporation of deteriorating items, shortage cost and stochastic lead time in order to develop more complex and realistic inventory models.
\end{abstract}

Keywords- Inventory, Demand, Stock, Costs, Storage.

\section{INTRODUCTION}

As we know that in all conventional studies of inventory, the rate of demand is taken to be a constant. There are several inventory models which have been proposed for dealing with deterministic and probabilistic demand. In all these models it is assumed that the rate of demand is independent and an outside parameter is not affected by any internal policy of inventories. In our real life, however, it is generally, noticed that the demand for any particular product can be affected by internal reasons such as price and availability of the inventory. All the models, in which variation demand is considered in response to inventory level, follow the constant holding cost for whole cycle of inventory, where shortages not allowed. The present paper proposes an inventory model in which the rate of demand depends on a linear stock, holding cost is variable and shortages are allowed- depend. Here the holding cost is considered as an increasing step function of the time due to storage. This study is shows many our real-life conditions in which different unit holding cost comes and depends on the stock, stored in warehouse. It is especially true in the storage of perishable and decaying (deteriorating) items such as fruits in which quantity decreasing every time so the holding cost. Key Words: Inventory, demand, stock, costs.

The first inventory model studied by Harris In 1995 and it was generalized by Wilson in 1934; he proposed a formula for economic order quantity. In 1957 Whit gave an inventory model about the deterioration of the fashion related goods at the end of the agreed shortage period. In 1963, model for Ghare and Schrader proposed a model for exponentially decaying items. In 1981, Dave and Patel gave the first inventory model to study a deteriorating inventory for linearly increasing demand without shortages. After that in 1993, Chung and Ting gave many inventory models in this field; they divided inventory models with different parameters such as stock-level and variation demand. An inventory model presented by Ouyang and Cheng in 2007 for decaying items with partial backlogging and exponential decaying demand. In 2007, Alamri and Balkhi studied some inventory models on the effects of learning and forgetting on the optimal production lot size for deteriorating items with timevarying demand and deterioration. In 2007, Dye et al also proposed an optimal selling price lot size model with a variable deterioration and exponential, shortages and partial backlogging. In their study they consider that a part of customers who backlog their orders increases exponentially as the waiting time for the next replenishment decreases. In 2008, Roy presented an inventory model where the rate of deterioration rate was proportional to time. In 2009, Pareek et al. proposed an inventory model for perishable with shortages and re-sale value. In 2013, Mishra and Singh studied an inventory model for quadratic demand, time-dependent perishable items with recover value and shortages. And perishable time dependent inventory model with variable (time) holding cost wand partial backlogging. An inventory model with common type of demand, deterioration 
and backlogging proposed by Hung in 2013. In 2013, Mishra et al. also proposed an inventory model for perishable items with time-dependent demand, time-varying holding cost and partial backlogging. In 1990, Datta and Pal was studied the models on same pattern. In 1997, Sarker, Mukherjee and Balan considered inventory-level dependent demand and introducing a totally new concept of decrease in demand. In 1973, Montgomery, Bazarra and Keswani proposed both deterministic and probabilistic models considering the situation in which, during the stock-out period a part of demand is backordered and rest is lost forever. In 1997, Rosenberg proposed a lot-size inventory model with partial backlogging and taken fictitious demand rate that helps to understand the previous proposed inventory models. In 1995, Padmanabhan and Vrat proposed an inventory model for perishable items by taking constant deterioration rate, introducing the three cases of complete, partial and without backlogging. In 2001, Zeng studied an inventory model and optimised the total cost by using the concept of partial backordering.

In traditional inventory models, the rate of demand and holding cost are considered to be constant. In real life situations the rate of demand and holding cost for physical items may be considered time dependent or stock dependent. As we know that the time has very important role in the study of inventory theory, so, in the present study, the demand is considered as stock dependent up to reorder point and holding cost is taken as an increasing function of time. In this study, holding cost is assumed per unit of the item per unit time to be linear function of the quantity in storage.

\section{ASSUMPTIONS AND LIMITATIONS}

The mathematical model in this paper is developed on the basis of the following assumptions and limitations.

1. Lead time is considered as zero

2. The rate of replenishment is infinite.

3. The size of replenishment is finite.

4. The shortages are allowed.

5. A single item is considered.

6. At time $t_{k}$ the stock level reaches to zero shortages come after it.

7. The rate of demand $(\mathrm{P})$ rate is increasing linear function of the stock- level $\mathrm{I}(\mathrm{t})$.

8. There is varying holding cost and is considered as an increasing step function of the storage quantity.

9. Every time we place the order of Q quantity units at the beginning of the cycle is such that the order level reaches to the pre-specified value $\mathrm{L}$ and after fulfilling the backorder quantity Q-L.

10. The rate of demand (L) is a linear function of the inventory level.

\section{NOTATIONS}

The mathematical model in this paper is developed on the basis of the following notations.

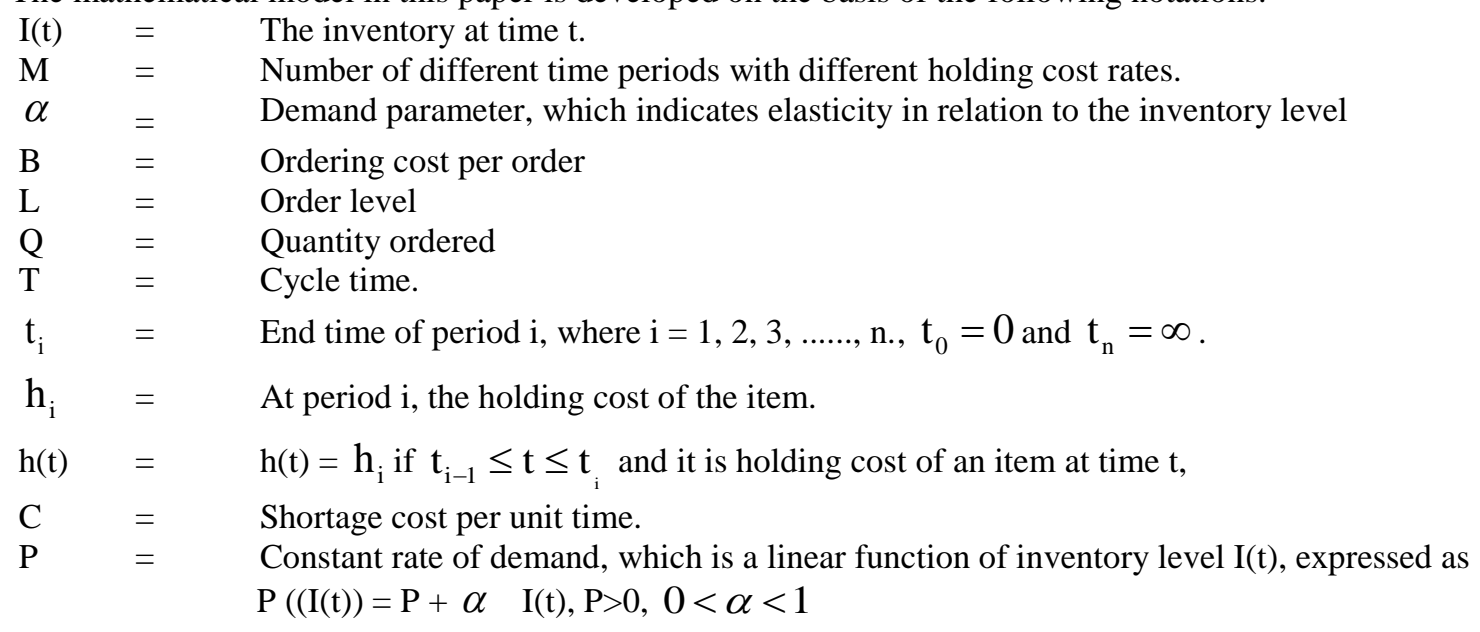

\section{MATHEMATICAL FORMULATION AND SOLUTION OF THE MODEL}

In the present paper our aim is to optimize (minimize) the total inventory cost (TIC) per unit time, which have three components: The holding cost, the ordering cost, and the shortage cost. As it is made one order per cycle, therefore the per unit time, ordering cost is as follows. 
Ordering cost per cycle $=\frac{B}{T}$

It is assumed that $t_{s}$ i.e $I\left(t_{s}\right)=0$

Now we obtain holding cost (HC) per cycle as follows

$$
\mathrm{HC}=\int_{0}^{\mathrm{t}_{\mathrm{s}}} \mathrm{h}(\mathrm{t}) \mathrm{I}(\mathrm{t}) \mathrm{dt}
$$

The quantity ordered Q and realized in stock and after fulfilling the back orders Q-L the order level reaches to the order level L. At the end of the cycle the inventory level reaches to Q-L.

The instantaneous states of $\mathrm{I}(\mathrm{t})$ in the interval $(0, \mathrm{~T})$ is given by

$$
\frac{\mathrm{dI}(\mathrm{t})}{\mathrm{dt}}= \begin{cases}-(\mathrm{P}+\alpha \mathrm{I}(\mathrm{t})), & 0 \leq \mathrm{t}<\mathrm{t}_{\mathrm{s}} \\ -\mathrm{P} & \mathrm{t}_{\mathrm{s}} \leq \mathrm{t}<\mathrm{T}\end{cases}
$$

The solution of the above differential equation is

$$
\frac{\mathrm{dI}(\mathrm{t})}{(\mathrm{P}+\alpha \mathrm{I}(\mathrm{t}))}=-\mathrm{dt}
$$

On integrating, we have

$$
\begin{aligned}
& \frac{1}{\alpha}[\ln (\mathrm{P}+\alpha \mathrm{I}(\mathrm{t}))-\ln (\mathrm{P}+\alpha \mathrm{I}(0))]=-\mathrm{t} \Rightarrow \ln \left(\frac{\mathrm{P}+\alpha \mathrm{I}(\mathrm{t})}{\mathrm{P}+\alpha \mathrm{L}}\right)=-\alpha \mathrm{t} \\
& \Rightarrow \mathrm{P}+\alpha \mathrm{I}(\mathrm{t})=(\mathrm{P}+\alpha \mathrm{L}) \mathrm{e}^{-\alpha \mathrm{t}} \\
& \mathrm{I}(\mathrm{t})=\frac{1}{\alpha}\left[(\mathrm{P}+\alpha \mathrm{L}) \mathrm{e}^{-\alpha \mathrm{t}}-\mathrm{P}\right], 0 \leq \mathrm{t}<\mathrm{t}_{\mathrm{s}}
\end{aligned}
$$

Now, from equation (2): $\frac{\mathrm{dI}(\mathrm{t})}{\mathrm{dt}}=-\mathrm{P}$, solving it, we have

$$
\mathrm{I}(\mathrm{t})=-\mathrm{P}\left(\mathrm{t}-\mathrm{t}_{\mathrm{s}}\right), \mathrm{t}_{\mathrm{s}} \leq \mathrm{t} \leq \mathrm{T}
$$

Now from the equations (3) and (4), put the values of $\mathrm{I}(\mathrm{t})$ in equation (2)

$$
\mathrm{I}(\mathrm{t})= \begin{cases}-\frac{1}{\alpha}\left[(\mathrm{P}+\alpha \mathrm{I}(\mathrm{t})) \mathrm{e}^{-\alpha \mathrm{t}}-\mathrm{P}\right], & 0 \leq \mathrm{t}<\mathrm{t}_{\mathrm{s}} \\ -\mathrm{P}\left(\mathrm{t}-\mathrm{t}_{\mathrm{s}}\right), & \mathrm{t}_{\mathrm{s}} \leq \mathrm{t}<\mathrm{T}\end{cases}
$$

Now from $(5), I(T)=-P\left(T-t_{s}\right)=Q-L$, so we have

$$
\mathrm{T}=\mathrm{t}_{\mathrm{s}}-\frac{\mathrm{Q}-\mathrm{L}}{\mathrm{P}} \text { and } \mathrm{Q}=\mathrm{L}-\mathrm{P}\left(\mathrm{t}-\mathrm{t}_{\mathrm{s}}\right)
$$

At $\mathrm{t}=\mathrm{t}_{\mathrm{s}}, \mathrm{I}(\mathrm{t})=0$, using this in equation (5), we have

$$
\begin{aligned}
& \left(\frac{\mathrm{P}}{\alpha}+\mathrm{L}\right) \mathrm{e}^{-\alpha \mathrm{t}_{\mathrm{s}}}-\frac{\mathrm{P}}{\alpha}=\mathrm{P}(0)=0 \\
& \Rightarrow \mathrm{t}_{\mathrm{s}}=\ln \left(\left(\frac{\mathrm{P}}{\alpha}+\mathrm{L}\right) \frac{\mathrm{P}}{\alpha}\right)
\end{aligned}
$$

Now we determine cost of shortages 


$$
S C=-C \int_{t_{s}}^{T} I(t) d t=-C \int_{t_{s}}^{T} P\left(t-t_{s}\right) d t
$$

Solving it, we have

$$
\mathrm{SC}=-\mathrm{CP}\left[\frac{\left(\mathrm{T}-\mathrm{t}_{\mathrm{s}}\right)^{2}}{2}\right]
$$

Now we determine retroactive holding cost and it is the holding cost of last storage period applied retroactively to all previous cycles as after the cycle $t_{s-1}$ to $t_{s}$ shortages take place.

$$
\begin{aligned}
\text { Holding cost } & =\mathrm{h}_{\mathrm{s}} \int_{0}^{\mathrm{t}_{\mathrm{s}}} \mathrm{I}(\mathrm{t}) \mathrm{dt}=\mathrm{h}_{\mathrm{s}} \int_{0}^{\mathrm{t}_{\mathrm{s}}}\left[\left(\frac{\mathrm{P}}{\alpha}+\mathrm{L}\right) \mathrm{e}^{-\alpha \mathrm{t}}-\frac{\mathrm{P}}{\alpha}\right] \mathrm{dt} \\
& =\mathrm{h}_{\mathrm{s}}\left\{\frac{1}{\alpha}\left(\frac{\mathrm{P}}{\alpha}+\mathrm{L}\right)\left(1-\mathrm{e}^{-\alpha \mathrm{t}}\right)-\frac{\mathrm{P}}{\alpha}\right\}
\end{aligned}
$$

Total inventory Cost $(\mathrm{TIC})=$ Ordering Cost + Shortage Cost + Holding Cost

$$
=\frac{\mathrm{B}}{\mathrm{T}}-\mathrm{CP}\left[\frac{\left(\mathrm{T}-\mathrm{t}_{\mathrm{s}}\right)^{2}}{2}\right]+\mathrm{h}_{\mathrm{s}}\left\{\frac{1}{\alpha}\left(\frac{\mathrm{P}}{\alpha}+\mathrm{L}\right)\left(1-\mathrm{e}^{-\alpha \mathrm{t}}\right)-\frac{\mathrm{P}}{\alpha}\right\}
$$

Now put the value of $\mathrm{T}$ from equation (6), we have

$$
\begin{aligned}
& \mathrm{TIC}=\frac{\mathrm{P}}{\mathrm{Pt}_{\mathrm{s}}-\mathrm{q}-\mathrm{L}}\left[\mathrm{B}-\frac{\mathrm{C}(\mathrm{Q}-\mathrm{L})^{2}}{2 \mathrm{P}}+\mathrm{h}_{\mathrm{s}} \mathrm{Z}\right] \\
& \text { Where } \mathrm{Z}=\frac{1}{\alpha}\left(\frac{\mathrm{P}}{\alpha}+\mathrm{L}\right)\left(\mathrm{i}-\mathrm{e}^{-\alpha \mathrm{t}}\right)-\frac{\mathrm{P}}{\alpha} \mathrm{t}_{\mathrm{s}}
\end{aligned}
$$

Differentiating (11) with respect to $\mathrm{Q}$ and equating to zero, we have

Solving it for Q, we have

$$
\mathrm{C}(\mathrm{Q}-\mathrm{L})\left(\mathrm{Pt}_{\mathrm{s}}-\mathrm{Q}+\mathrm{L}\right)+\mathrm{P}\left[\mathrm{B}-\frac{\mathrm{C}(\mathrm{Q}-\mathrm{L})^{2}}{2 \mathrm{P}}+\mathrm{h}_{\mathrm{s}} \mathrm{Z}\right]=0
$$

$$
\mathrm{Q}=\mathrm{L}-\mathrm{Pt}_{\mathrm{s}}+\left[\mathrm{P}^{2} \mathrm{t}_{\mathrm{s}}{ }^{2}-\frac{2}{\mathrm{C}}\left(\mathrm{PB}+\mathrm{PMh}_{\mathrm{s}}\right)\right]^{\frac{1}{2}}
$$

\section{CONCLUSION}

The model presented here obtained an optimal order quantity for stock-level dependent demand, where the holding cost is a decreasing step function of the storage quantity. In the present model retroactive increase holding cost is used to find the optimal result. The model shows that both the optimal order quantity and the time of optimal cycle. When the holding cost increase, the time of one cycle is decreased. This study provides the basis for further extensions like the incorporation of deteriorating items, shortage cost and stochastic lead time in order to develop more complex and realistic inventory models. Although this paper does not include any statistical inventory models but it still puts a platform for developing statistical optimal inventory policy if demand or lead time uncertainties are incorporated. In this study the consideration of decreasing holding cost also applies the facilities of rented storage, where the rates of lower rent are generally found for long term leases.

\section{REFRENCES}

1. Wilson RH (1934) a scientific routine for stock control. Harv Bus Rev 13:116-128

2. Whitin TM (1957) The theory of inventory management. Princeton: Princeton University Press.

3. Ghare PM, Schrader GF (1963) A model for an exponentially decaying inventory. Journal of Industrial and Engineering Chemistry 14:238-243.

4. G. Zoutendijk, Nonlinear Programming: A Numerical Survey, SIAM J. Control. 4 (1966) 194-210. 
5. Baker, R.C., Urban, T.L., 1988a. A deterministic inventory system with an inventory level dependent rate. Journal of the Operation Research Society 39 (9), 823-831.

6. Baker, R.C., Urban, T.L., 1988b. Single-period inventory dependent demand models. Omega-The International Journal of Management Science 16 (6), 605-607.

7. B. N. Mondal and S. Phaujder, An inventory model for deteriorating items and stock-dependent demand rate, Opl. Res. Soc. 40 (1989) 483488.209

8. Datta, T.K and Pal A.K. (1990). “ A note on an inventory model with inventory-level dependent demand rate”, Journal of the Operational Research Society, 41 (10), 971-975.

9. T. K. Datta and A. K. Pal, A note on an inventory model with inventory level-dependent demand rate, Opl.Res. Soc. 41 (1990) 971-975.

10.T. L. Urban, An inventory model with an inventory-level-dependent demand rate and relaxed terminal condition, Opl. Res. Soc. 43 (1992) $721-$ 724

11.M. Goh, EOQ models with general demand and holding cost functions,Euro. J. Oper. Res.73 (1994) $50-54$.

12. B. C. Giri, S. Pal, A. Goswami and K. S. Chaudhuri, An inventory model for deteriorating items with stock-dependent demand rate, Euro.J.Oper. Res.95 (1995) 604-610.

13. Wee HM (1995) a deterministic lot-size inventory model for deteriorating items with shortages and a declining market. Computers \&Operations Research - Journal 22:345-356 Publisher Full Text

14. Urban, T.L., 1995. Inventory models with the demand rate dependent on stock and shortage levels. International Journal of Production Economics $40(1), 2-28$.

15. Ray, J., Chaudhuri, K.S., 1997. An EOQ model with stock dependent demand, shortage, inflation and time discounting. International Journal of Production Economics 53 (2), 171-180

16. J. Roy and K. S. Chaudhuri, An EOQ model with stock-dependent demand, shortages, inflation and time discounting, Int. J. Prod. Eco. 53 (1997) 171-180.

17. J. Roy, A. Goswami and K. S. Chaudhuri, on an inventory model with two levels of storage and stock-dependent demand rate, Int. J.Systems. Sci.29 (1998) 249-254.

18. Chang HJ, Dye CY (1999) An EOQ model for deteriorating items with time varying demand and partial backlogging Journal of the Operational Research Society 50:1176-1182

19. Hwang, H., Hahn, K.H., 2000. An optimal procurement policy for items with an inventory level dependent demand rate and fixed life time. European Journal of Operation

20. Goyal SK, Giri BC (2001) recent trends in modelling of deteriorating inventory. European Journal of Operational Research 134:1-16Publisher Full Text International Journal of Production Economics 113:852-861 Publisher Full Text

21. Ouyang W, Cheng X (2005) an inventory model for deteriorating items with exponential declining demand and partial backlogging.Yugoslav journal of operations research 15(2):277-288Publisher Full Text

22. Alamri AA, Balkhi ZT (2007).Tithe effects of learning and forgetting on the optimal production lot size for deteriorating items with time varying demand and deterioration rates. International Journal of Production Economics 107:125-138 Publisher Full Text

23. Dye CY, Ouyang LY, and Hsieh TP (2007) Deterministic inventory model for deteriorating items with capacity constraint and time proportional Backlogging rate. . European Journal of Operational Research178 (3):789-807 Publisher Full Text

24. Alfares, H. K., 2007. Inventory model with stock-level dependent demand rate and variable holding cost.Int. J. Production Economics 108 (2007) 259-265

25. Liao JJ (2008) An EOQ model with non instantaneous receipt and exponential deteriorating item under two-level trade credit.and time-varying demand, Quality and Quantity, 38, 457-473.

26. Mishra VK, Singh LS (2011) Inventory model for ramp type demand, time dependent deteriorating items with salvage value and shortages. International Journal of Applied Mathematics and Statistics 23(D11):84-91

27. Mishra et al. (2013) An inventory model for deteriorating items with time-dependent demand and time-varying holding cost under partial backlogging. Journal of Industrial Engineering International 2013, 9:4

28. Inventory Model for Deteriorating Items with Fixed Life under Quadratic Demand and Nonlinear Holding Cost. International Journal of Engineering and Innovative Technology (IJEIT) Volume 3, Issue 12, June 2014

\section{Author Profile}

Dr. Sandeep Kumar is working as an associate professor at Department of Applied Sciences, Dewan VS Institute of Engineering and Technology, Meerut. He has more than 15 years of experience of research and teaching of graduate and post graduate classes. His areas of interest include Numerical Optimization and Operations Research, Discrete mathematics, Graph Theory, Computer Graphics, Theory of automata, Engineering Mathematics etc. He has published many research papers in various journals and conferences of national and international repute. He has also published various books and working for many other books 